\title{
A preliminary approach for modelling the effects of cropping systems on the dynamics of broomrape (Phelipanche ramosa) in interaction with the non-parasitic weed flora
}

\author{
Nathalie COLBACH ${ }^{1,2}$ \\ Nadia ABDENNEBI-ABDEMESSED ${ }^{1}$ \\ Stéphanie GIBOT-LECLERC ${ }^{1}$ \\ ${ }^{1}$ INRA, AgroSup Dijon, UMR 1210 \\ biologie et gestion des adventices, \\ 21000 Dijon, France \\ $<$ Nathalie.Colbac@dijon.inra.fr > \\ ${ }^{2}$ UMR 1210 biologie et gestion des \\ adventices, 17, rue Sully, BP 86510, \\ 21065 Dijon cedex, France
}

\begin{abstract}
The current decrease in herbicide use may increase and diversify weed flora in crops as well as companion bioagressors spreading via weeds. Among these bioagressors is Phelipanche ramosa (L.) Pomel, a parastic plant which is very harmful on oilseed rape. The objective of the present work was to develop a new model (called Pherasys) of the effects of cropping systems on parasite dynamics, in interaction with non-parasitic weed hosts. The structure of this first model version was based on models developed for other parasitic plants and on FlorSys which quantifies the effects of cropping systems on nonparasitic weed flora. PheraSys was parametrized with preliminary values from literature and expert opinion, connected to FlorSys for weed host predictions and used to simulate parasite dynamics in a few contrasting cropping systems.
\end{abstract}

Keywords: cropping system, weed, parasitic plant, broomrape, Phelipanche ramosa (L.) Pomel, model, oilseed rape, Brassica napus $L$.

\section{Introduction}

Because of environmental and health safety issues, European and national legislators have called for a drastic decrease in herbicide applications. As a consequence, weeds are expected to increase and diversify in crops, together with a series of companion bioagressors among which parasitic weeds from the Orobanchaceae family. In France, Phelipanche ramosa (L.) Pomel (Joel, 2009) is the most frequent and harmful species (Benharrat et al., 2005; Gibot-Leclerc et al., 2006). It has been reported in 27 departments and can cause up to $80 \%$ of yield loss in its favourite crop, i.e. oilseed rape (Gibot-Leclerc et al., 2009). Phelipanche ramosa can infect a wide range of crops (tobacco, hemp, melon...) as well as weeds (Gibot-Leclerc et al., 2009; GibotLeclerc et al., 2003; Boulet et al., 2007) and is thus expect to proliferate in case of less stringent weed control.

At present, there are no commercial herbicides available against $P$. ramosa and curative measures are limited to manual weeding (Rubiales et al., 2009). The control of the parasite is mostly based on preventive methods such as tillage to limit the contact of host roots and parasite seeds (Rubiales et al., 2009), growing false hosts (which stimulate parasite germination but are immune to fixation) and trap plants (which stimulate germination and are destroyed before parasite seed production) to stimulate fatal parasite germination (Lins et al., 2006), or decreasing the frequency of susceptible crops and varieties in the rotation (Buschmann et al., 2005). Consequently, cultivation techniques must be judiciously chosen and combined to

To cite this article: Colbach N, Abdennebi-abdemessed N, Gibot-leclerc S. A preliminary approach for modelling the effects of cropping systems on the dynamics of broomrape (Phelipanche ramosa) in interaction with the non-parasitic weed flora. OCL 2011;18(1):39-45. doi : 10.1684/ocl.2011.0360 
optimize cropping systems to control both the parasite and susceptible non-parasitic weeds.

It is now well recognized that models that quantify the effects of cropping systems on pest dynamics are valuable tools to synthesize knowledge on bioagressor life-cycle and design management strategies (Aubertot et al., in press; Rossing et al., 1997; Colbach, 2010). To understand and predict the variability in effects observed for given techniques and to use these models in a large range of conditions without reparametrising, mechanistic approaches where life-cycles are split into sub-processes depending on biological and physical effects of cropping systems, in interaction with the biological (e.g. weed stage) and physical conditions (e.g. soil structure) are necessary (Colbach and Debaeke, 1998; Colbach et al., 2005). Consequently, the objective of the present paper was to analyze existing weed dynamics models and literature data on parasitic weeds to develop a preliminary model of cropping system effects on the dynamics of $P$. ramosa, in interaction with non-parasitic weed flora.

\section{Material and methods}

\section{Model organization}

The analysis of existing weed dynamics models in literature (see reviews by (Colbach, 2010; Colbach and Debaeke, 1998; Colbach et al., 2005; Doyle, 1997; Holst et al., 2007)) showed that to date, only two models answer our requirements for a mechanistic model based on biophysical sub-models predicting processes as a function of cropping systems and environmental conditions. These are the monospecific prototype AlomySys (Colbach et al., 2006a; Colbach et al., 2006b; Colbach et al., 2007) developed for an annual grass weed (i.e. Alopecurus myosuroides Huds.) and its multi-specific successor FLORSYs (Colbach et al., 2008a; Gardarin, 2008; Colbach et al., 2010a). The life-cycle of $P$. ramosa has not yet been modelled but another species of Orobanchaceae, Orobanche crenata, has already been tackled (Grenz et al., 2005).

In the present work, we developed a new model called PHERASYs for the effects of cropping systems on the dynamics of Phelipanche ramosa. The structure of the new model was inspired by that of FLORSYs for those processes that parasitic and non-parasitic weeds have in common (e.g. seed movements during tillage); specific parasitic stages were described according to the $\mathrm{O}$. crenata model. The input variables of FLORSYS and PHERASYs consist of:

- the above-ground climate: temperature and rainfall for each simulated day;

- a description of the simulated location: soil texture and depth, initial soil structure (fragmented, intermediate, compacted) and initial soil moisture (dry, intermediate, moist); - the initial weed seed bank: seed density for each weed species, soil layer ( 30 soil layers ranging from 0 to $30 \mathrm{~cm}$ ) and seed age class (freshly produced vs. older than one year);

- the cropping system during the whole simulated period, comprising the crop sequence including set-aside and cover crops, the date of all operations (tillage, sowing, herbicides, mechanical weeding, mowing, nitrogen fertilization, manure, harvest) and their characteristics, i.e. tool, working depth etc. for tillage, active ingredient, rate and conditions (good, intermediate, bad) for herbicides, seed density and row spacing for sowing, and total applied rate for nitrogen fertilization.

In addition, PheraSys uses several intermediate and output variables produced by FlorSys (figure 1):

- the proportions of seeds moved between soil layers during tillage, depending on tillage characteristics and soil structure; - soil hydro-thermal conditions: temperature, soil moisture and water potential for each day and soil layer are predicted with a submodel extracted from STICS (Brisson et al., 1998); - the density of crop and weed plants as well as their root lengths in each soil layer.

These input variables influence the annual life-cycle of nonparasitic weeds in FLORSYs (Colbach et al., 2008a; Gardarin, 2008; Colbach et al., 2010a) and of the parasite in PheraSys.

\section{Model equations and parameters of PHERASYS \\ Seed movements during tillage}

Tillage moves soil and seeds, and the degree of burial depends on the tillage implement. For instance, mouldboard ploughing buries more fresh seeds than tilling with a chisel or a covercrop. In PHERASYs, a matrix equation is used to transfer $P$. ramosa seeds between soil layers (table 1, Eq. [1]). The seed movement matrix is estimated by FLORSYS as a function of tillage and soil structure.

\section{Seed mortality}

Daily in situ seed mortality (Eq. [3]) includes any seed disappearance caused by seed age, diseases or microscopic predators, but excludes any seed bank decrease due to germination which is calculated separately. Surface predation due to birds, rodents or beetles etc. was neglected. Seed mortality was higher in moist vs. dry conditions (Eq. [2]). As no data was available for $P$. ramosa, the parameter values from O. crenata were used (Grenz et al., 2005).

\section{Pre-conditioning of seeds}

Pre-conditioning, i.e. exposure to certain temperature and moisture conditions, is necessary to make seeds susceptible to host root exsudates (Eq. [4] to [6]). It takes three weeks

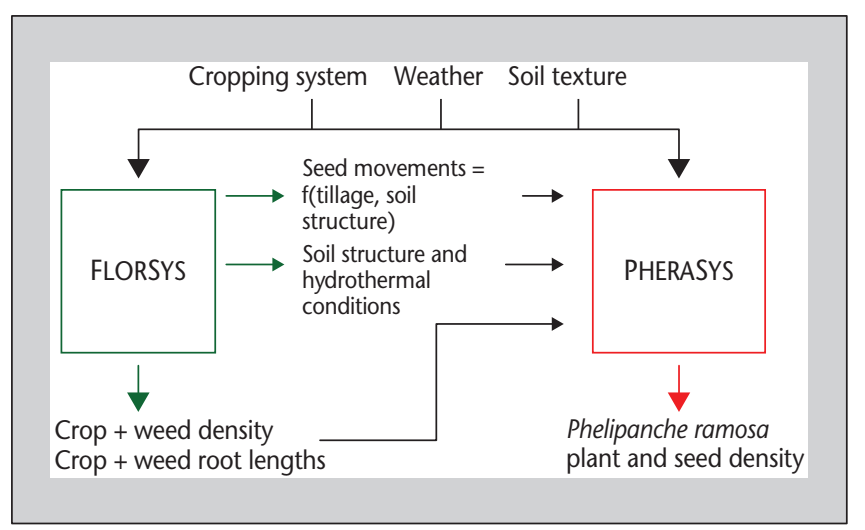

Figure 1. Input and output variables of the newly developed PHERASYS model predicting the dynamics of the parasitic weed Phelipanche ramosa, in interaction with soil environment and weed variables predicted by the existing FLORSYS model developed for non-parasitic weeds (Colbach et al., 2008a; Gardarin, 2008; Colbach et al., 2010a). 
Table 1. Comprehensive list of equations relating state variables describing life-stages of Phelipanche ramosa in PHERASYS.

\begin{tabular}{|c|c|c|c|c|}
\hline Eq. & When & Process & Equation & Explication \\
\hline [1] & During tillage & Seed movements & {$\left[\mathrm{SB}_{\mathrm{fd}}^{\prime}\right]=\left[\mathrm{st}_{\mathrm{sfi}}\right] \cdot\left[\mathrm{SB}_{\mathrm{id}}\right]$} & $\begin{array}{l}\mathrm{SB}=\text { viable seeds } / \mathrm{m}^{2} \\
\mathrm{st} \text { sfi }=\text { proportion of seeds moved during } \\
\text { tillage from layer } i \text { to layer } f \text { in } \\
\text { case of soil structure } s\end{array}$ \\
\hline [2] & Daily, $\forall I$ & Seed mortality & $\begin{array}{l}\text { If } \chi_{\text {Id }}>\chi_{\text {base }} \alpha=0.0025 \\
\text { Else } \alpha=0.0005\end{array}$ & $\begin{array}{l}\alpha=\text { daily seed mortality rate } \\
\chi_{\mathrm{Id}}=\text { soil water potential } \\
\chi_{\text {base }}=\text { base water potential of } \\
\text { P. ramosa }=-2 \mathrm{MPa}\end{array}$ \\
\hline [3] & Daily, $\forall \mathrm{I}$ & Seed mortality & $S^{\prime} B_{l d}^{\prime}=(1-\alpha) S B_{l d}$ & \\
\hline [4] & Daily, $\forall I$ & Pre-conditioning & $\begin{array}{l}\text { If } \chi_{\mathrm{ld}} \in[-2,-0.02 \mathrm{MPa}] \\
\text { and } \theta_{\mathrm{ld}} \in\left[10,25^{\circ} \mathrm{C}\right] \\
\text { ndp++ }\end{array}$ & $\begin{array}{l}\mathrm{ndp}=\text { number of days the seeds spent in } \\
\text { conditions favouring pre-conditioning }\end{array}$ \\
\hline [5] & Daily, $\forall I$ & Pre-conditioning & $\begin{array}{l}\text { If } n d p<n d p_{\max } \beta_{\text {ld }}=n d p / n d p_{\max } \\
\text { If } n d p \in[21,100 \text { days }] \beta_{\text {ld }}=1 \\
\text { If } n d p>100 \beta_{\text {ld }}=0\end{array}$ & $\beta_{\mathrm{Id}}=$ proportion of pre-conditioned seeds \\
\hline [6] & Daily, $\forall \mathrm{I}$ & Pre-conditioning & $P S_{I d}=\beta_{I d} \cdot S B_{I d}$ & $\mathrm{PS}_{\mathrm{Id}}=$ preconditioned seeds $/ \mathrm{m}^{2}$ \\
\hline [7] & $\begin{array}{l}\text { End of crop } \\
\text { susceptibility } \\
\text { period, } \forall \mathrm{l}\end{array}$ & Germination & $\chi_{l}=\frac{\prod \cdot \sum_{e}\left(\left(\mathrm{~d}_{\max }+\mathrm{rd}_{\mathrm{h}} / 2\right)^{2} \cdot \mathrm{N}_{\mathrm{dh}} \cdot \mathrm{R}_{\mathrm{ldh}}\right)}{0.01 \cdot 1}$ & $\begin{array}{l}\chi_{\mathrm{I}}=\text { proportion of germinated seeds } \\
d_{\text {max }}=\text { maximum stimulation distance } \\
\text { from host root }=0.5 \mathrm{~mm} \\
\mathrm{rd}_{\mathrm{h}}, \mathrm{N}_{\mathrm{de}}, \mathrm{R}_{\mathrm{Ide}}=\text { root diameter, plant } \\
\text { density and cumulated root length } \\
\text { of host species } \mathrm{h}\end{array}$ \\
\hline [8] & $\begin{array}{l}\text { End of crop } \\
\text { susceptibility } \\
\text { period, } \forall \mathrm{l}\end{array}$ & Germination & $\begin{array}{l}G_{l}=\chi_{l} P S_{I d} \\
S B_{l d}^{\prime}=S B_{l d}-G_{l}\end{array}$ & $\mathrm{G}_{\mathrm{l}}=$ germinated seeds $/ \mathrm{m}^{2}$ \\
\hline [9] & $\begin{array}{l}\text { End of crop } \\
\text { susceptibility } \\
\text { period }\end{array}$ & Fixation & $\mathrm{F}=\sum_{l=0}^{29} G_{l}$ & $\mathrm{~F}=$ number of fixations $/ \mathrm{m}^{2}$ \\
\hline [10] & $\begin{array}{l}\text { End of crop } \\
\text { susceptibility } \\
\text { period }\end{array}$ & Emergence & $p E=1-\exp \left(-\frac{\mathrm{F} / \sum_{\mathrm{e}} \mathrm{N}_{\mathrm{dh}}}{\delta_{\mathrm{h}}}\right)$ & $\begin{array}{l}\mathrm{pE}=\text { probability that a fixed parasite } \\
\text { emerges } \\
\delta_{\mathrm{h}}=\text { maximum number of parasite } \\
\text { fixations per plant of host species } h\end{array}$ \\
\hline$[11]$ & $\begin{array}{l}\text { End of crop } \\
\text { susceptibility } \\
\text { period }\end{array}$ & Emergence & $\mathrm{P}=\sum_{h}\left(\mathrm{~N} h \cdot \delta_{h} \cdot p E\right)$ & $\mathrm{P}=$ parasite plants $/ \mathrm{m}^{2}$ \\
\hline [12] & Crop harvest & Seed production & $\varepsilon_{\mathrm{h}}=\frac{\text { days since crop sowing }}{30}$ & $\begin{array}{l}\varepsilon_{\mathrm{h}}=\text { parasite biomass per plant }(\mathrm{g}) \\
\text { on host species } h\end{array}$ \\
\hline [13] & Crop harvest & Seed production & $S=P \cdot \varepsilon_{h} \cdot \phi$ & $\begin{array}{l}\phi=\text { viable parasite seeds per } \mathrm{g} \\
\text { biomass }=19,000\end{array}$ \\
\hline [14] & Crop harvest & Seed rain & $\mathrm{SB}^{\prime}{ }_{\mathrm{Od}}=\mathrm{SB}_{0 \mathrm{~d}}+\mathrm{S}$ & \\
\hline
\end{tabular}

I = soil layer (from 0 to 29), d = current day, s = soil structure class (fine earth, intermediate, compacted), h = host species, whether crop or weed. Variable names are explained at their first occurrence. A variable name $V^{\prime}$ refers to variable $V$ after the application of a process (ex. seed movements).

(Gibot-Leclerc et al., 2004) at a temperature between 10 and $25^{\circ} \mathrm{C}$ (Gibot-Leclerc et al., 2004; Goldwasser and Yoder, 2001; Zehhar et al., 2002) and a soil water potential between - 2 and - $0.02 \mathrm{MPa}$ (Gibot-Leclerc et al., 2004) to increase the rate of pre-conditioned seeds from $0 \%$ at seed maturity to $100 \%$. After 100 days in pre-conditioning conditions, the rate of preconditioned seeds drops again to zero (Gibot-Leclerc et al., 2004).

\section{Seed stimulation and germination}

Seeds must be located at less than $4 \mathrm{~mm}$ from a exsudating host root to be stimulated by host root exsudates and become able to germinate (Gibot-Leclerc, 2004). PheraSys thus calculates the volume of soil in each soil layer that is located close enough to host roots, as a function of host plant density and cumulated root lengths in each soil layer (Eq. [7]). The latter two variables concern both crop and non-parasitic weed species and are predicted by FLORSYs though the prediction is at present very simplistic. The soil volume reached by root exsudates is then divided by the total soil layer volume to obtain the proportion of stimulated and germinated parasite seeds. The germinated seeds are calculated once, when the crop no longer produces root exsudates stimulating parasite seeds (e.g. $1006{ }^{\circ} \mathrm{C}$ days in oilseed rape, (Gibot-Leclerc, 
Table 2. Crop management in the reference cropping system with a oilseed rape/winter wheat/winter barley rotation simulated with PHERASys.

\begin{tabular}{|c|c|c|c|}
\hline Cultivation technique & Oilseed rape & Winter wheat & Winter barley \\
\hline Manure & $43 \mathrm{~m}^{3} / \mathrm{ha}$ à $7.5 \mathrm{~kg} \mathrm{~N} / \mathrm{m}^{3}$ (15 July) & None & None \\
\hline \multirow[t]{4}{*}{ Tillage } & Chisel (15 July) & Chisel (15 Aug.) & Covercrop (1 Aug.) \\
\hline & $2 \times$ covercrop (1 Aug.) & Chisel (10 Sept.) & Chisel (21 Aug.) \\
\hline & Power harrow (15 Aug.) & Spring tine (10 Oct.) & Spring tine (10 Sept.) \\
\hline & Spring tine (27 Aug.) & & Power harrow (8 Oct.) \\
\hline Sowing date & 27 Aug. & 10 Oct. & 8 Oct. \\
\hline Sowing density (seeds $/ \mathrm{m}^{2}$ ) & 56 & 344 & 330 \\
\hline \multirow[t]{4}{*}{ Herbicides $^{1}$} & Trifluraline (26 Aug.) & $\begin{array}{l}\text { lodosulfuron-méthyl-sodium } \\
+ \text { mésosulfuron-méthyl (12 March) }\end{array}$ & $\begin{array}{l}\text { Imazaméthabenz-méthyl } \\
\text { (7 Nov.) }\end{array}$ \\
\hline & Napropamide (26 Aug.) & $\begin{array}{l}\text { 24MCPA + fluroxypyr + clopyralid } \\
\text { (5 April) }\end{array}$ & Isoproturon (7 Nov.) \\
\hline & $\begin{array}{l}\text { Clomazone + dimétachlore } \\
\text { + napropamide (26 Aug.) }\end{array}$ & & \\
\hline & Quizalofop-éthyl isomère D (5 Oct.) & & \\
\hline Nitrogen fertiliser (kg/ha) & $\begin{array}{l}75 \text { (15 Feb.) } \\
75 \text { (15 March) }\end{array}$ & $\begin{array}{l}65 \text { (15 Feb.) } \\
92 \text { (15 March) } \\
33 \text { (16 April) }\end{array}$ & $\begin{array}{l}55 \text { (15 Feb.) } \\
65 \text { (15 March) }\end{array}$ \\
\hline Harvest date & 12 July & 18 July & 2 July \\
\hline
\end{tabular}

Soil texture was $36 \%$ clay, $58 \%$ loam and $6 \%$ sand, with $1 \%$ of stones. Soil depth was $90 \mathrm{~cm}$.

${ }^{1}$ Herbicides were never applied at the total regulatory rate, but usually at only $66-80 \%$ of the rate. Applications were carried out at optimal conditions and times and therefore still produced the maximum efficiency rate of the product.

2004)), and retracted from the surviving parasite seed bank (Eq. [8]).

\section{Parasite fixation and plant emergence}

All germinated parasite seeds are assumed to infect a host root (Eq. [9]) as parasite temperature and moisture requirements are usually met after crop sowing (Gibot-Leclerc et al., 2004). However, only a fraction of the fixated parasites succeeds in producing an emerged plant. PHERASYs assumes that each host plant can fix a maximum of $\delta_{\mathrm{h}}$ emerged parasite plants, with $\delta_{\mathrm{h}}$ depending on the host species (Eq. [11]). For instance, no more than 20 parasite plants can fix and emerge per oilseed rape host plant (Gibot-Leclerc et al., 2006). Below this maximum, a density-dependent relationship is used where the probability of emergence of a fixed parasite decreases with increasing number of fixations per host plant (Eq. [10]). Emergence probability does not depend on seed depth (as in the case of non-parasitic weeds) because, thanks to its host plant, the parasite presents a shoot that is sufficiently large not to be hindered by soil clods (Gardarin et al., 2010).

\section{Seed production}

At present, no destructive operations are available in crops, so all emerged parasite plants reach maturity. Parasite maturity coincides with crop maturity, regardless of the crop species (Gibot-Leclerc, 2004). Seed production is therefore calculated at crop harvest, with the number of seeds increasing with the parasite biomass (Eq. [13]). As no data was available for $P$. ramosa, the relevant parameter value for $O$. crenata was used (Grenz et al., 2005). The latter increases with the growth duration since parasite emergence (approximately since crop sowing, Eq. [12]) and is therefore larger when infesting oilseed rape than tobacco (Buschmann et al., 2005). The newly produced seeds are added to the top layer of the soil seed bank (Eq. [14]).

\section{Simulations}

The reference cropping system was a winter oilseed rape $(\mathrm{OSR}) /$ winter wheat $(\mathrm{WW}) /$ winter barley (WB) rotation, identified as the most common rotation in farm surveys carried out in Côte d'Or, Burgundy (Eastern France) (Colbach et al., 2008b). Table 2 shows the crop management used for the different crops of the rotation. In addition to the reference system, five alternative scenarios were tested (table 3). The six cropping systems were simulated first with PHERASYs without any non-parasitic weeds; a second run simulated the dynamics of $P$. ramosa in the presence of a weed density typical of the tested systems (table 3 ). All simulations started with 1000 P. ramosa seeds in the top soil layer and lasted for 27 years. When simulating the reference system, weather scenarios were chosen randomly each year among available data sets from Dijon from 1986 to 2004. The same list of weather scenarios was then used for the remaining cropping system simulations.

\section{Results}

Figure 2 shows the dynamics of the parasite soil seed bank with time in the reference OSR/WW/WB cropping system (hence $\mathrm{R}$ system). Soil seed bank gradually increased over time with enormous increases after the susceptible crop OSR and smaller reductions during the non-susceptible cereal crops. After three repetitions of the rotation (i.e. 9 years), the soil seed bank more or less stabilized around a sill value. Reducing 
Table 3. Summary of cropping systems simulated with PHERASYs, with and without non-parasitic weeds.

\begin{tabular}{|c|c|c|c|c|}
\hline \multicolumn{2}{|l|}{ Cropping system } & \multirow[t]{2}{*}{ Modification relative to reference } & \multicolumn{2}{|c|}{ Non-parastic weed density (plants/m²) } \\
\hline & & & No weeds & With weeds \\
\hline Reference & $\mathrm{R}$ & See Table 2 & 0 & 10 \\
\hline Diversified rotation & SP & Spring pea after barley & 0 & 0.1 \\
\hline Mouldboard ploughing & MP & Ploughing before winter wheat & 0 & 5 \\
\hline No tillage & NT & No tillage before any crop & 0 & 100 \\
\hline Low density & LD & Sowing density of 40 seeds $/ \mathrm{m}^{2}$ in OSR & 0 & 12 \\
\hline Delayed sowing & DS & All crop sowings delayed by 3 weeks & 0 & 5 \\
\hline
\end{tabular}

Non-parasitic weed densities were estimated from prior simulations with the monospecific prototype ALomySys (Colbach, 2009; Colbach et al., $2010 \mathrm{~b}$ ) because the programming of the connection between the PHERASYS and FLORSYS softwares is still underway.

the frequency of susceptible crops in the rotation by adding a spring pea after barley (hence DR system) delays the advent of the sill by three years. Even then, the infestation was still lower after OSR in the DR vs. R simulation. More importantly, the seed bank was considerably lower before sowing the susceptible OSR crop in the DR vs. R system (figure 3). Burying parasite seeds deeply with mouldboard ploughing (MP) did not reduce parasite density. Conversely, the no-till system (NT) was practically parasite-free because there was little chance of contact between the parasite seeds on soil surface and the host roots below. A lower OSR sowing density (LD) slightly decreased parasite seed bank as it resulted in a lower probability of root presence in the parasite vicinity. Delayed sowing (DS) very slightly reduced parasite density because more parasite seeds died before sowing. In all cases, parasite density increased when the field was infested with non-parasitic weeds. The increase was though negligible when non-parasitic weed density was low as in the DR system. Conversely, it was enormous in the NT system where weeds were frequent, resulting in the highest parasite density of all tested systems.

\section{Discussion}

The present work demonstrated that it is possible to develop a partially mechanistic model of cropping systems effects on the

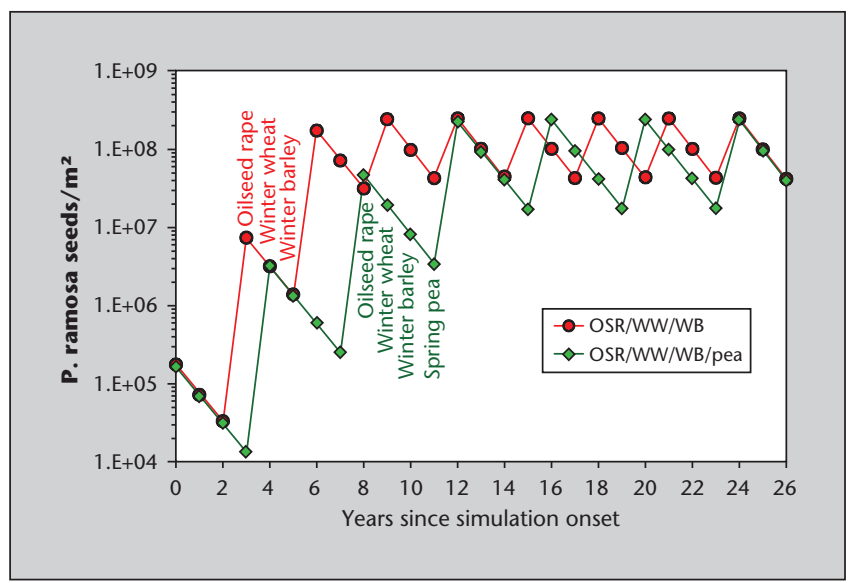

Figure 2. Density of Phelipanche ramosa soil seed bank after crop harvest with time simulated with PHERASYs for two different rotations in the absence of non-parasitic weeds. dynamics of parasitic weeds. The development of the prefixation soil processes largely benefitted from our previous extensive modelling research on non-parasitic weeds though the submodel was parametrized with data from other species (i.e. seed mortality rate of 0 . crenata). The post-fixation submodel was developed based on results from in vitro experiments (Gibot-Leclerc et al., 2009; Gibot-Leclerc et al., 2003; Gibot-Leclerc et al., 2004) but some stages still remain unclear (e.g. emergence rate of fixations). The post-emergence submodel was rudimentary and entirely based on an existing $O$. crenata submodel. This first modelling attempt for $P$. ramosa thus identified major areas on which research should concentrate, among which post-emergence host-parasite relationships and variability in parasite behaviour in different crops.

The present simulations showed the major importance of nonparasitic weeds for the dynamics of the parasite. Though the ability of various weed species to stimulate and fix parasite germinations has already been widely studied (Gibot-Leclerc et al., 2003), the reproductive ability of the parasite on different weeds has rarely been investigated. table 4 though list the most weed species most sensitive to $P$. ramosa that farmers should well control in their crops if they have $P$. ramosa problems. Germination-stimulating non-parasitic weeds could be used during the intercrop season to stimulate fatal parasite

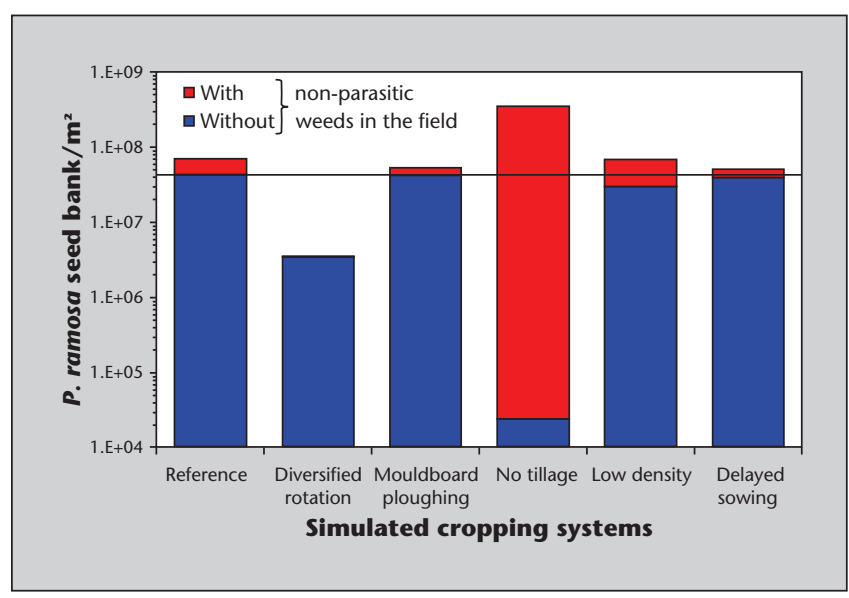

Figure 3. Density of Phelipanche ramosa soil seed bank before oilseed rape crops in different cropping systems after 12 years of simulation with PheRASYs, either with or without non-parasitic weeds. For details of cropping systems and weeds, see table 3. 
Table 4. Weed species most sensitive to Phelipanche ramosa (GibotLeclerc et al., 2009; Gibot-Leclerc et al., 2003).

\begin{tabular}{|ll|}
\hline Aphanes arvensis & Mercularis annua \\
\hline Calepine irregularis & Picris echioides \\
\hline Capsella bursa-pastoris & Raphanus raphanistrum \\
\hline Crepis foetida & Senecio vulgaris \\
\hline Euphorbia helioscopa & Sonchus asper \\
\hline Geranium dissectum & Sonchus oleraceus \\
\hline Geranium molle & \\
\hline
\end{tabular}

germinations and thus contribute to reducing the parasite seed bank at crop sowing. This though assumes that pre-sowing tillage and herbicides are sufficiently efficient to destroy all infested weeds.

Among the tested options, zero tillage appeared as particularly interesting for controlling P. ramosa, as long as non-parasitic weeds were rare. This is though only true if parasite seeds remain on soil surface during the whole crop season and do not migrate closer to crop roots due to soil fissures and rain, which is only partially true (Mohler et al., 2006). This also assumes that there are no crop roots sufficiently close to soil surface to stimulate parasite germination. Unfortunately, our knowledge on root growth is much more limited than on above-ground growth and development, and root growth is rarely integrated into cropping system models though it exists in crop models (Keating et al., 2003). This is another interesting future research question.

The simulations also show that once P. ramosa infests the field, it steadily increases until reaching a sill value characteristic of the rotation. This indicates that parasite control must be applied as soon as a field is even only slightly infested. As there are as yet no curative techniques and as other cultural measures are only partially efficient, this mostly means avoiding parasite-susceptible crops in the rotation for several years (Rubiales et al., 2009).

\section{Conclusion}

The present work was an exploratory study to evaluate the possibility to develop a mechanistic model of cropping system effects on the dynamics of parasitic weeds, producing a preliminary version of PHERASYs. This version not only demonstrated the feasibility of our modelling objective but also identified the major areas on which future research on the parasite should concentrate. The preliminary model also shows how such a model can be used for evaluating existing and prospective cropping system scenarios. Though consistent with existing knowledge on P. ramosa dynamics, these simulation results should be considered as an illustration of the model's future use. Indeed, they were based on a PHERASYs parametrized with data obtained for another parasite species or from expert opinion. Considerable future work is necessary to improve our knowledge on the parasite life-cycle in different crops and management situations.
Acknowledgements. The present work was financed by INRA, ANR OGM VIGIWEED (ANR-07-POGM-003-01) and Regional Action Plan for Innovation (PARI 20109201AAO050S01397) of Burgundy region.

\section{REFERENCES}

Aubertot JN, Lescourret F, Bonato O, et al. How to improve pest management in cropping systems. Effects of cultural practices on pest development. A review. Agron Sustain Dev.

Benharrat H, Boulet C, Theodet C, Thalouarn P. Virulence diversity among branched broomrape (O. ramosa L.) populations in France. Agron Sustain Dev 2005; 25: 123-8.

Boulet C, Pineault D, Benharrat H, Simier P, Delavault P. Adventices du colza et orobanche rameuse. In: XX Conférence du Columa : Journées internationales sur la lutte contre les mauvaises herbes. Dijon, France: AFPP, 2007.

Brisson N, Mary B, Ripoche D, et al. STICS: a generic model for the simulation of crops and their water and nitrogen balances. I. Theory and parameterization applied to wheat and corn. Agronomie 1998; 18: 311-46.

Buschmann H, Gonsior G, Sauerborn J. Pathogencity of branched broomrape (Orobanche ramosa) populations on tobacco cultivars. Plant Pathology 2005; 54: 650-6.

Colbach $\mathrm{N}$. Évaluation de systèmes de culture régionaux et tests de scénarios prospectifs réduisant herbicides et travail du sol. INRA 17 p 2009.

Colbach N. Modelling cropping system effects on crop pest dynamics: how to compromise between process analysis and decision aid. Plant Sci 2010; 179: 1-13.

Colbach N, Debaeke P. Integrating crop management and crop rotation effects into models of weed population dynamics: a review. Weed Sci 1998; 46: 717-28.

Colbach N, Dürr C, Roger-Estrade J, Caneill J. How to model the effects of farming practices on weed emergence. Weed Res 2005; 45: 2-17.

Colbach N, Busset H, Yamada O, Dürr C, Caneill J. ALOMYSYS: modelling black-grass (Alopecurus myosuroides Huds.) germination and emergence, in interaction with seed characteristics, tillage and soil climate. II. Evaluation. Eur J Agron 2006; 24: 113-28.

Colbach N, Dürr C, Roger-Estrade J, Chauvel B, Caneill J. ALOMYSYS: modelling blackgrass (Alopecurus myosuroides Huds.) germination and emergence, in interaction with seed characteristics, tillage and soil climate. I. Construction. Eur J Agron 2006; 24: 95-112.

Colbach N, Chauvel B, Gauvrit C, Munier-Jolain NM. Construction and evaluation of ALOMYSYS, modelling the effects of cropping systems on the blackgrass life-cycle. From seedling to seed production. Ecol Modelling 2007; 201: 283-300.

Colbach N, Gardarin A, Granger S, Guillemin JP, Munier-Jolain NM. La modélisation au service de l'évaluation et de la conception des systèmes de culture intégrés. Proceedings of Carrefour de l'Innovation. In: Huyghe C, (ed.); Dijon, France, 2 décembre 2008 ; p. 61-73

Colbach N, Sassi A, Granger S. ALOMYSYS: a model for evaluating and developing cropping systems for integrated weed management. In: Proceedings of 10th congress of the European Society for Agronomy. Bologne (Italie), 15-19 septembre 2008.

Colbach N, Gardarin A, Munier-Jolain NM. FLORSYS: a mechanistic model of cropping system effects on weed flora based on functional relationships with species traits. In: Proceedings of 15th International EWRS Symposium. Kaposvár, Hungary, 12-15 July 2010. 
Colbach N, Kurstjens DAG, Munier-Jolain NM, Dulout-Dalbiès A, Doré $\mathrm{T}$. Assessing non-chemical weeding strategies through a modelling approach applied to blackgrass (Alopecurus myosuroides Huds.) dynamics. Eur J Agron 2010; 32: 205-18.

Doyle CJ. A review of the use of models of weed control in integrated crop protection. Agric Ecosyst Environ 1997; 64: 165-72.

Gardarin A. Modélisation des effets des systèmes de culture sur la levée des advnetices à partir de relations fonctionnelles utilisant les traits des espèces. PhD Thesis, Université de Bourgogne, Dijon, France. 2008.

Gardarin A, Dürr C, Colbach N. Effects of seed depth and soil structure on the emergence of weeds with contrasted seed traits. Weed Res 2010; 50: 91-101.

Gibot-Leclerc S. Étude épidémiologique, écophysiologique et agronomique du couple Orobanche ramosa L./Brassica napus. PhD Thesis, Université Pierre et Marie Curie, Paris, France. 2004.

Gibot-Leclerc S, Brault M, Pinochet X, Sallé G. Rôle potentiel des plantes adventices du colza d'hiver dans l'extension de l'orobanche rameuse en Poitou-Charentes. Comptes Rendus de Biologie 2003; 326: 645-58.

Gibot-Leclerc S, Corbineau F, Sallé G, Côme D. Responsiveness of Orobanche ramosa L. seeds to GR 24 as related to temperature, oxygen availability and water potential during preconditioning and subsequent germination. Plant Growth Regulation 2004; 43: 63-71.

Gibot-Leclerc S, Pinochet X, Sallé G. Orobanche rameuse (Orobanche ramosa L.) du colza : un risque émergent sous surveillance. OCL 2006; 13: 200-5.

Gibot-Leclerc S, Charles J, Dessaint F. Sensibilité d'hôtes potentiels visà-vis de deux pathovars d'Orobanche ramosa L. In: XIII ${ }^{\mathrm{e}}$ Colloque
International sur la Biologie des Mauvaises Herbes, Dijon, France; 2009. p. 446-456.

Goldwasser Y, Yoder JI. Differential induction of Orobanche seed germination by Arabidopsis thaliana. Plant Science Letters 2001; 160: 951-9.

Grenz JH, Manschadi AM, De Voil P, Meinke H, Sauerborn J. Assessing strategies for Orobanche sp. control using a combined seedbank and competition model. Agronomy Journal 2005; 97: 1551-9.

Holst N, Rasmussen IA, Bastiaans L. Field weed population dynamics: a review of model approaches and applications. Weed Res 2007; 47: 1-14.

Joel DM. The new nomenclature of Orobanche and Phelipanche. Weed Res 2009; 49: 6-7.

Keating BA, Carberry PS, Hammer GL, et al. An overview of APSIM, a model designed for farming systems simulation. Eur J Agron 2003; 18 : 267-88.

Lins RD, Colquhoun JB, Mallory-Smith CA. Investigation of wheat as a trap crop for control of Orobanche minor. Weed Res 2006; 46: 313-8.

Mohler CL, Frisch JC, McCulloch CE. Vertical movement of weed seed surrogates by tillage implements and natural processes. Soil Tillage Res 2006; 86: 110-22.

Rossing WAH, Meynard JM, van IMK. Model-based explorations to support development of sustainable systems: case studies from France and the Netherlands. Europ / Agron 1997; 7: 271-83.

Rubiales D, Fernandez-Aparicio M, Wegmann K, Joel DM. Revisiting strategies for reducing the seedbank of Orobanche and Phelipanche spp. Weed Research. Weed Res 2009; 49: 23-33.

Zehhar N, Ingouff M, Bouya D, Fer A. Possible involvement of gibberellins and ethylene in Orobanche ramosa germination. Weed Research (Japan) 2002; 42: 464-9. 